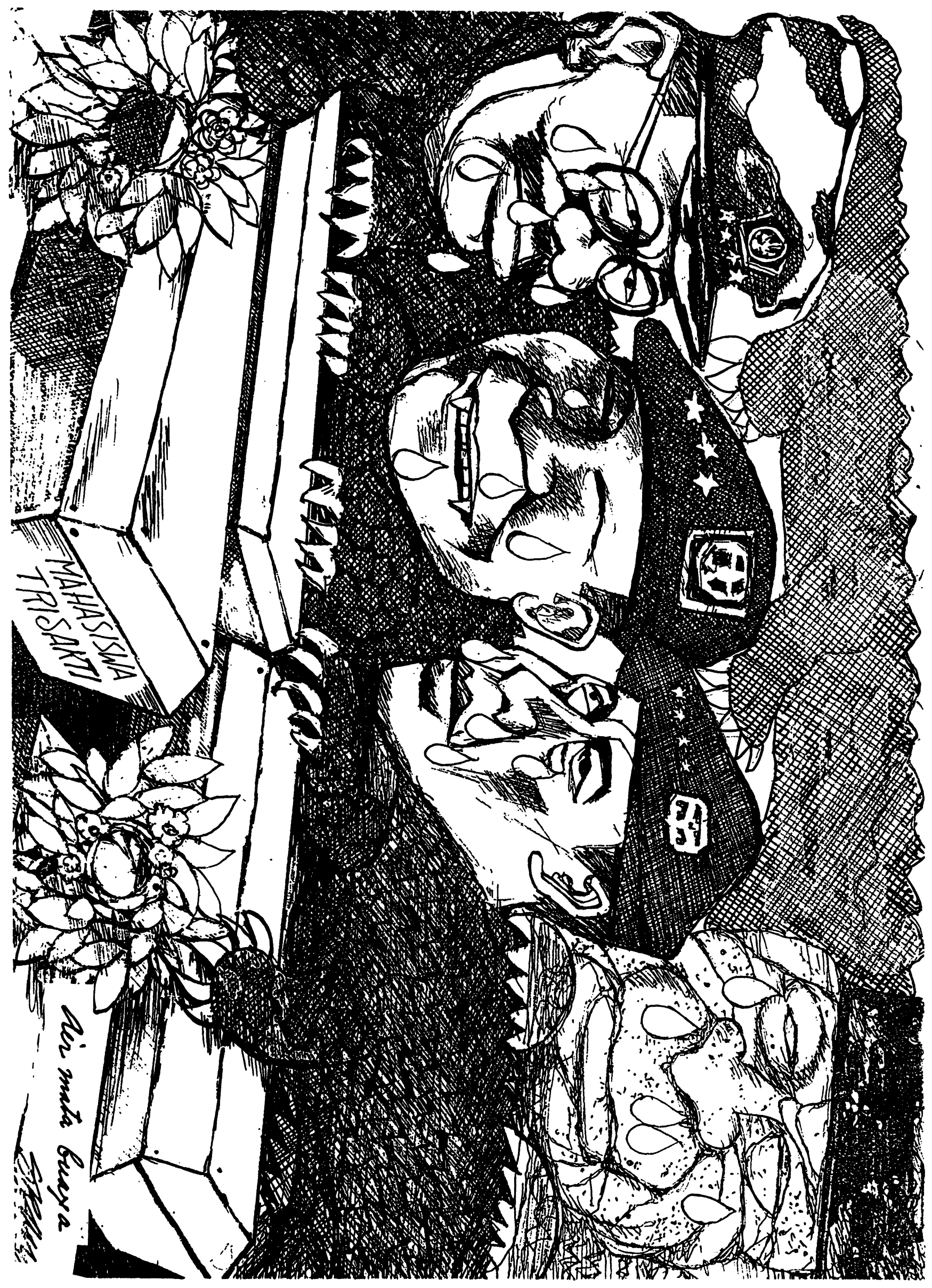




\section{EARLY THOUGHTS ON THE VIOLENCE OF MAY 13 AND 14, 1998 IN JAKARTA}

James T. Siegel

While Suharto was in power there was practically no one who accused him of corruptly using up the people's money. Were they to have done so, their fate was evident: it is certain they would end up in jail.

Haruskah (daripada) Soeharti diadili? [Must Suharto be brought to trial? Rather than that ... ?] Ummat, June 8, 1998, p. 14.

The artless confession in this news magazine, speaking to and about the middle class, helps in understanding the course of events that led up to the resignation of President Suharto. By May 1998 Indonesia had shared in the economic difficulties of East Asia for ten months, and though a great many people were feeling its effects and there was much political discontent, no one seemed to have anticipated Suharto's resignation. After it took place, however, people in Jakarta, though initially surprised, thought it was easily explicable. Suharto left office after two violent incidents. Students, who had originally demonstrated against the rise in prices that accompanied the fall in value of the rupiah had begun to demand Reformasi (Reform), sometimes in effect taking up the vocabulary of the IMF when they asked for "transparency" which, for a while, was an important word of political rhetoric. ${ }^{1}$ Students at the private

1 "Transparency" of course was used to indicate the possibility of knowing the true state of financial institutions and also public access to awarding of contracts etc. It soon was used to describe the desirability of political events also being open to view. It had no antonym except perhaps in KKN, "Kolusi, korupsi, nepotism" (collusion, corruption and nepotism), it being assumed that what was hidden from view was corrupt and that corruption in the New Order took those three forms. The use of visual metaphors throughout the period deserves attention. Here I only note that the demands for "reformasi" were not demands for representation but insistence that the political system be open to view. It is truly 
76 James T. Siegel

Trisakti University in Jakarta, known by the term "mamas' children," because they often came from privileged families, had been late to join the demonstrations. However they too began protests. On May 12, in the course of a rally, four Trisakti students were shot dead, presumably by police who were then accused of using real rather than rubber bullets; soon after it was widely thought that elements from the army had done the shooting. In the afternoon of the next day, May 13, rioting broke out against Indonesian Chinese in many parts of Jakarta, continuing on May 14. The riots continued the following day. Students from Jakarta and elsewhere occupied the grounds and the roof of the National Assembly, the military mysteriously allowing them to so. On May 17. Harmoko, the speaker of the Assembly, a long-time servile follower of Suharto, called for his resignation. Subsequently fourteen of Suharto's ministers resigned, and he could not find people to serve on the new Reform Commission. A major demonstration was called off on May 20 when Amien Rais, the head of the Muslim organization Muhammadiyah, announced that a certain general, later rumored to be Lt. General Prabowo, the son-in-law of President Suharto, had said that it would lead to bloodshed. On May 21, President Suharto resigned. The train of events seemed to the many people with whom I spoke in June 1998 to be self-evident. But if so, it is because events which were at first surprising were set within the workings of Indonesian political discourse and made to seem natural.

The last years of the New Order saw political protest of various sorts. The strongest was no doubt the long struggle of the inhabitants of East Timor resisting their forced inclusion in Indonesia after the invasion of that former Portuguese colony in 1975. Student demands, however, made no mention of East Timor. Crowds gathered outside Cipinang Prison when President Habibie released the labor leader Mochtar Pakpahan and other political prisoners, but no student delegations were present. ${ }^{2}$ That the students failed to include the causes of labor or of the Timorese or of other groups, such as Aceh Merdeka, for instance, in their demands partly reflects their newness on the political scene. Their appearance was, in fact, so recent that one is hard put to say who their leaders were and what it is that they wanted. Interviewed after the National Assembly sit-in, one, a "supply coordinator" for the students occupying the National Assembly, formulated their demands this way: "[We want] to change the regime now

\footnotetext{
"reform" and not, of course, "revolution." Exposure, one can say, became a political idea first with "transparency" and then with rape.

2 So at least go the news reports of the event which sometimes list groups present to greet the released prisoners but make no mention of students. See for example, "Tapol/Napol: Bebas Semua atau Tidak?" $D E R$, June 6, 1998, pp. 24-25; and see "Merdeka! Atau Bebas," Ummat, June 8, 1998, p. 29, etc. Ummat is close to ICMI (Association of Indonesian Muslim Intellectuals), the group of Muslim leaders formed by Habibie when he was vice president. The newsweekly $D \mathcal{E} R$ is perhaps the most influential of the weeklies, meaning the most au courant of political gossip; it largely took the place of the banned weekly Tempo. Ummat is reformist Islamic in outlook.
}

I should point out that this piece concerns only Jakarta. In other areas, students united or tried to unite with other groups. Jakarta is, of course, the city where the middle class is most developed. Army policy was to keep students separated from other groups; in Jakarta it easily succeeded. There were youth groups in Jakarta who, during the late New Order, were interested in coalitions but their influence was not apparent during the events of May. 
in power for a new bureaucratic elite more favorable to the people." 3 One notes the lack of space left for the seething masses.

The protesters' failure to offer much in the way of a political program, along with their failure to take up the demands of labor and regional groups, cannot simply be explained by the recent appearance of students on the political scene nor, as the magazine Ummat suggests, by the fact that until recently political protest meant jail. There were those such as Mochtar Pakpahan, or inhabitants of Timor Timur and Aceh, who made their demands felt knowing that they would be jailed or killed. If students did not act earlier it is because, despite occasional discontent, most of them tacitly supported a regime which did so much to establish the class to which they belonged. Only when the "krismon" (the acronym for "krisis moneter" or "monetary crisis" became acute, did they act. An explanation based on interests alone however will not entirely explain the inflections of political discourse in the aftermath of the events of May. These events brought up questions of the relations between classes and the place of race and sex in national identity.

Let us start with the students. President Habibie, the successor to President Suharto, proclaimed the four murdered Trisakti students "Heroes of Reform." They were, one journal said, "inscribed as makers of a new history." 4 To be a hero of reform seems almost an oxymoron, reform being usually gradual and peaceful in contrast to revolution. If the predicate "hero" seemed appropriate for the victims, however, it was not only because they were shot dead, but also because the word implicitly referred to earlier moments when, during the revolution and again at the beginning of the New Order, youths moved events forward in violent circumstances. As usual in Indonesia, forward movement was put in terms of generations. Furthermore, students borrowed much of the iconography of the revolution. But these students were quite different from their nationalist forebears. Unlike in the 1930s, when parents of young nationalists were often thought to belong to a world of custom and hence were considered incapable of understanding their children, or during the revolution, when youth acted without much reference to parents, in May 1998 there was an understanding between parents and children (if not between generations as such, which is a wider political term). Parents of students and alumni of Jakartan universities brought the protesters provisions as they occupied the National Assembly. Students are reported to have acted with the consent of their parents, not merely sought their approval afterwards. The usual norms of familial behavior were still in force. The days of heroic reform were not a period of license but of normal relations between the sexes. Female students often continued to make themselves up on the grounds of the National Assembly - that is, to look at once attractive and proper-and there was the same sort of flirting that took place on the campuses. ${ }^{5}$ There was scarcely anything rebellious about their actions. In demanding Suharto's resignation, they were merely asking for what their parents too wanted. By comparison, the students who abducted

\footnotetext{
3 "Saya Kurang Ngerti Politik, tapi ..." [I don't understand politics, but ... l, Panji Masjarakat, June 10, 1998, pp. 47ff. Panji Masjarakat is connected with the Muslim organization Muhammadiyah. This interesting article has much about the students' behavior during their occupation of the National Assembly grounds. Panji Masjarakat is an Islamic reformist journal of long standing.

4 Ibid.

${ }^{5}$ Conversations with various students; also "Saya Kurang Ngerti Politik, tapi ...," pp. 47ff.
} 
Sukarno in order to make him proclaim national independence were ahead of their elders.

My interest is in the popular political assumptions of the middle class as they were refracted in explanations of the events. Before the burning and pillaging began, it was not only the middle class that was interested in a change of regime; the lower classes as well felt the pressure of the sudden regression of the economy. There was a high rate of unemployment while some of those still with jobs found their salaries inadequate to feed their children. Thus at the moment that the riots of May 13 and 14 began, a student, speaking for "the people" (rakyat), could assume that they, "the people," were behind him. Students, however, quickly refused an alliance with those on the street. In retrospect, it was widely thought that the actions of "massa," as such people were called, were instigated from above. But it took time for this opinion to be generated. The students' refusal of an alliance when one seemed possible had other causes as well.

Here is the experience of one student at Trisakti University where four student demonstrators were shot. It was reported in a woman's weekly. ${ }^{6}$ Alya Rohali is a television actress as well as a student. ${ }^{7}$ She went to the Trisakti campus, three kilometers from her house, on Wednesday, May 13, the day after the four students were shot and the day the riots broke out, in her own car. Various speeches, called by the term, scarcely used until recently, "orasi" in Indonesian were given by various "orator" (Indonesian) including Adnan Buyung Nasution, a famous lawyer and civil rights activist. Some students went on to the burial ceremonies for two of their slain comrades. Others stayed at the university. The latter were still on the university grounds when the riots broke out. The military had allowed demonstrations on the condition that they be confined to university campuses. In her statement Alya says that the people on the street asked the students to join them.

"I really remember how at the time some people wanted us to gather outside the campus. But we refused. Because of that they ["they" here refers to the rioters, referred to as massa meaning "mass" or "masses"] started to throw things toward the campus," related Alya. "Fortunately the massa actions didn't get any of us," she added.

Alya was worried when she saw that the atmosphere around the campus was tinged with the clash between the massa and the security apparatus. To control the brutal massa actions, the [security] apparatus, indeed, used tear gas. 8

6 "Hadapi Gas Air Mata Pakai Softlens: Pengalaman Jadi Demonstran Trisaskti," Nyata, June 11, 1998, p. 2.

7 Alya Rohali was involved in a controversy when, elected Miss Indonesia, she was attacked by certain Muslim groups for partipating in immoral activities, i.e., the beauty contest. She was also rumored to be a candidate for marriage with Tommy Suharto, the president's son, who, however, married someone else. The references to the "favorite" Cakra car, the car made by Tommy's company, probably allude to that piece of history.

${ }^{8}$ I am told by Benny Subianto that it is unusual for the Jakarta security forces to use tear gas. That they did so no doubt was an effect of the situation aroused by the killing of the students.

As we will see, it was unusual for the police to act at all on May 13. They were notable for their nearly complete absence. That they were present at Trisakti was no doubt because of the student killings and not in response to the street demonstrations. That the police acted against the people on the streets around Trisakti indicates that, if the security apparatus was in collusion with street demonstrators elsewhere, it was not the case there. 
Indeed, Alya panicked when she was hit by the gas. "In all my whole life, this was the first time I was hit by tear gas," Alya said. "Fortunately, I had on softlens," [italicized in original] she said with a smile.

The activist students, some of whom had come to Jakarta from various regions to participate in the political events, were shocked to see action begin on the street and were often quick to disown it. In this case, Alya was already afraid to join with the people who, at this point, had yet to begin the looting, arson, and rape which marked the next two days. So far as she was concerned, to go on to the street was to defy the army and acknowledge a common cause with people she mistrusted. "... On the street its difficult to know our friends from our enemies and hard also to anticipate people who slip in with different goals," she says. She is afraid of who she will be with. Those who "slip in with different goals" might perhaps be looters, out to get what they can, and thus, in her mind, they deviate from the ends of the students and are perhaps misled by other protesters with indistinct, but different, aims. Or more likely they could be elements from the army or police who hope to incite students to violence, thus setting the stage for violent reprisals. Both students and those on the street have political goals. In Alya's judgment, the differences are that her comrades, while not exactly on the side of the law, at least act with the understanding of military authorities who, for instance, allowed them into the grounds of the National Assembly and permitted them to demonstrate within the confines of their campuses. The other difference between her and the massa concerns property. She and her friends do not want what does not belong to them. The rioters' relation to goods was much more ambiguous. On the one hand, the general events were commonly said to involve "looting" (penjarahan); on the other hand, the agents of this activity were rarely said to "loot" (menjarah) or to "steal" (curi), but were said merely to "take" (ambil) what they felt was theirs by a right whose nature we will ask about later. To anticipate for a moment, the difference comes when one chooses whether to think of these people as either "massa" or as "rakyat"; "the people" take out of need; the massa loot.

When they see the events on the street, Alya and her friends are afraid to stay on the campus and afraid also to leave. Finally, they climb the wall dividing their campus from that of a neighboring university, Tarumanegara, and from there enter the narrow side streets in back of campus, where it is calm. They are still afraid to enter the major avenues; they stay with a friend who lives nearby until, at nine in the evening, her father comes to get her. "'I was relieved to have Papa meet me,' said the girl born in Jakarta December 1, 1975."'

Despite her fear, she goes out again the next day. The situation has calmed, and she goes back to the campus.

Alya rushed to get her favorite Cakra sedan and move it to her grandmother's house in Kampung Melayu, Jakarta Timur. It was a good thing Alya's car was safe from the brutal actions of the massa. [In fact, 1119 cars were reported burned.] "Boy, if it were burned I would have been really upset. The price of cars these days is out of sight and there are fewer and fewer jobs," she said with a smile. ${ }^{9}$

\footnotetext{
${ }^{9}$ The number of cars burned is based on a figure from the National Commission on Human Rights as reported in Gatra, "Cerita Lain dari Kerusuhan" [Another Story from the Riots], June 13, 1998, p. 37.
} 
The reporter adds that the events of May 13 and 14 were "terrifying" [menyeramkan] and "really shook her" [mencekam]. Alya adds, "It was just like war. But I hope that nothing like that happens again. It really was terrifying ..." The reporter points out in the course of his article that Alya has had an experience which university students who want to be active demonstrators could keep in mind, particularly those who wear glasses for nearsightedness.

"During the demo on the campus, I was lucky to be wearing softlens. The tear gas could not get into my eyes. Its different from my friends; their eyes stung and watered. So my experience can be a lesson. Whoever wants to join a demo, wear softlens to protect against tear gas," said the student from the Law School in her eighth semester with a smile when she met Zulkarnaen from Nyata.

She, like many other students, was not afraid of the police but was "terrified" of the massa. The police (it was rumored later to be the army) killed four of her fellow students. But Alya is perfectly safe from them; she wears softlens. Nothing the police do harms her. What protects her is a cosmetic device which she presumably wears in the attractive photo which accompanies the article. We clearly see, no matter what lens we are wearing at the moment, the division of her sentiments. Alya is for "Reformasi" and herself gives a speech advocating reform of the economy. She is for a change of government and says that she wants President Habibie to have the chance to prove himself. She thinks the army chief, General Wiranto, would be an excellent president. She is against corruption, upset about the way the government has been run, and concerned about the economy. But what "terrorizes" her is the "massa" who, in her own discourse, acted by themselves, without direction from above, as was widely reported later. One should keep in mind too that her statement was made before stories of rape began to circulate. She has seen two kinds of violence. One is the arson and looting of the "masses." The other, which she did not see herself but which affected her enough to bring her back to the university after the shooting, was the killing of four of her comrades by the police. Only one of these events "terrified" her; the first. The second moved her but left her perfectly safe. This division of sentiments was widespread if not universal and is so much a part of Jakartan assumptions that it seems to go unremarked.

The police shot her comrades but she fears "the massa." It is a question of the softlens. It is not that she sees better with it. Rather, protecting her from the tear gas the police used against the "massa," it renders her fearless of them. Perhaps it is the way she looks. Her contact lenses are an element in the construction of her appearance, like her Cakra sedan, that assure her she is recognized for what she is: a member of the class the police usually protect. If, exceptionally, they shot her comrades, it does not change her essential position either toward them or toward those of the lower classes who for a moment seemed to share her interests. Her political vision, at least, is safe with her softlens.

\section{The Massa}

The "massa," it is agreed, were "brutal" and worse. Who exactly were they? In the first stories of the riots that were widespread in Jakarta, the "massa" were largely represented as local people. In Glodok, the old "Chinese" section of the city, a major 
shopping center was burned and looted and at least seventy homes destroyed as the flames from the market spread. The five-story market, a center for the sale of electronics, clothing, and so on, faced onto an older row of shops in front of which ran an arcade. On the sidewalk under the arcade, merchants, for the most part "pribumi," i.e., not "Chinese," sell various items. These merchants told us that when the massa approached, these small merchants, who knew them because they too were pribumi and because they too lived in the vicinity, told them to save these shops; to destroy them would mean that the livelihood of their neighbors also would be jeopardized. The shops were not touched. ${ }^{10}$ Across the street, a group of merchants standing in front of the burned-out shopping center where they formerly traded repeated the same story. From Pantai Indah Kapok, a new housing complex located in Pluit in the north of the city and occupied largely by "Chinese," there came a similar story. Here sixtyfour houses were burned out and over four hundred, which means most of them, were looted. ${ }^{11}$ People there told us that the looters were from the neighboring area, a part of the city crowded with series of shacks. The victims were furious; they felt betrayed by the police, the army, and the government who had failed to protect them and who, indeed, they were sure instigated the riots. Though to say "the government" instigated the riots would be too broad. Elements within the army, they were sure, had done it. "They came in trucks and some had on [military] boots." I heard this sentence more than once in just these words in several sections of the city. As in Glodok, we heard that before the local people arrived, others were already there, also arriving in trucks. In Glodok these early visitors had large crowbars they used to pry up the metal shutters of the shops. They then told the locals, mainly male youths, to help themselves to the goods. These military types then themselves spread gasoline and set the place afire. Of the about 1,100 people reported killed during the events of May 13 and 14, most of them are said to have been looters who died in these fires; but at the time of this writing, there seems to be no way to confirm how many actually died.

In East Jakarta, where again shopping centers were burned down, I was told by a friend that first people arrived in trucks, again wearing military boots. They set alight tires from whatever cars were nearby to attract locals. They then, he said, pried open the shop shutters, took out goods, and showed the locals that they could do the same. Then they left. My friend, a retired official of the Ministry of Religion, told me that local mosques used their loudspeakers to dissuade the looters from their work, but their efforts were only sometimes successful.

A secretary in her twenties told of leaving work at noon and crossing Jakarta to get home. There was only one bus running, and it went only part of the way. She walked for six hours before reaching home, by necessity often walking through looters at work. She remembered thinking as she watched them, "These are not human beings. They are animals." She heard the azan from the mosque chanting the call to prayer, without, in this case, any special message for the looters and thought, "What a contrast." She traversed a place where woman and children, among others, were carrying sacks of rice and cartons of Indo Mie (packaged noodles) out of a shop. Another woman said to them, "What you are doing is shameful. Its not human." The

${ }^{10} \mathrm{I}$ am indebted to Benny Subianto who accompanied me on this occasion.

11 This according to Sudarno Tasmin, "Chinese," a director of an insurance company and the neighborhood leader (kepala R.T.). I spoke with him on June 7, 1998 accompanied by Henri Chambert-Loir. 
woman who was busy with her stolen cartons answered in one word: "Chinese." The first one persisted, arguing "Chinese" too were human. But to no avail.

The secretary, let us call her Rahmah, went on to say

Some people think the looting was maneuvered by someone or other, but I don't think so. At the big malls, maybe, but not at these small shops. The trouble is that for so long these people have seen on tv, on the news, in the soap operas, how much luxury some people have. Now with the economy the way it is, they have nothing. There is such a gap and they have been patient for so long.

These sentiments and even the phrases about the enticement of television, particularly the soap operas, which are often about wealthy families and about the "gap" between rich and poor, have for a long time been heard in the press and in the speech of Jakartans who consider themselves middle class.

Rahmah is typical in sympathizing with the plight of the rioters but condemning their rioting. The suffering of "the people" is a common theme in the middle-class press. Rahmah does not want to deny it; quite the contrary. But she sees the actions of the looters as "inhuman." One does not excuse the other. She simply does not put the two attitudes in conjunction with one another to arrive at a consolidated conclusion.

Rahmah's thinking is similar to that of Alya's, who on the one hand advocates reform of the economy to help "the people" [rakyat] and at the same time perceives the looters [massa], through her softlens, as the chief danger to her safety. The difference between these two women, perhaps, is that Rahmah, never having taken a political position, was not forced to decide between the security forces and the massa. I asked Rahmah if she was not afraid on her travels home. She said no, that she was with many others, all forced to pass through looters at work. She, like the woman who chided the rioters, did not feel that she herself was in danger. She was not worried, for instance, at being thought "Chinese." The only time she was frightened, she said, was when soldiers fired into the air as she passed a shopping mall. Then she like everyone else ran. When I told her, "then you were afraid of ABRI" [the abbreviation for the Indonesian Armed Forces] she was surprised to find it was the case. In my opinion, however, she was not afraid of ABRI at all; she was afraid of guns.

That this young woman felt safe walking among the rioters shows the depths of her identification with them. She understands very well their need, and she understands as well the attraction that the goods in these stores have for them. On the other hand, she finds their actions deplorable. I do not doubt the sincerity of her conviction on either score. To say that she understands them is to say not only that she sympathizes with them in their situation, but also that she feels, with them, the lure of the enormous wealth displayed on television. The difference between her and the looters is that she would not give in to this attraction. It is just here that a question of class arises. The massa are, as looters, uncivilized. Their looting is an indication of how much further they need to develop. She is as certain of what separates them from her as she is of what links them to her.

The Indonesian middle class is not merely wealthier than the underclass; it is almost comfortable with its wealth; it does not feel it will be devoured by it. The lower classes, by contrast, are often suspicious of the effects of ownership of wealth while still finding it attractive. Those who can refrain from taking easily available market 
goods merit the title "middle class." Those who cannot may or may not still live in a traditional ambiance; whether or not this is the case, in Indonesia today they are sometimes identified as the massa and sometimes "the people," and there's no need, as we have seen, to pin them with a definitive judgment. In Europe, conflict between classes shaped class identity; in Indonesia, by contrast, class is largely the result of undesired distinctions within the body of the nation. Conflict has not played a large part in developing class identities. Rather attitudes toward wealth are a central point of differentiation.

If Rahmah feels safe during riots, it is not only because of the complicated quality of her identification with "the people." It is also because she is certain that she is not "Chinese" and that she will not be taken for "Chinese." Moreover, her understanding of the term "Chinese" matches the rioters' understanding, at least in part. She sees "Chinese" as having what the poor lack, and she ranges herself with those who have little. The "we" / pribumi and "they" / Chinese" divide along a question of wealth expressed as a question of race and appearance. For Rahmah, as for most members of the "pribumi" or "indigenous" middle class, the word "Chinese" distinguishes those so designated as rich relative to the comparatively poor pribumi, and this distinction continues to be accepted as true even when it doesn't fit the facts.

"Chinese" as used for certain inhabitants of Indonesia is a racial category, one that marks identity through inheritance of physical traits and moral characteristics. It supposedly designates those whose ancestors (or sometimes themselves) were born in China. "Chinese" are likely to be born in Indonesia, not to speak Chinese, and to have ancestors who may have intermarried with "pribumi"; they are not likely to have Chinese names. ${ }^{12}$ An inborn quality keeps them "Chinese," or so it is thought; this quality is the state of being wealthy, even when they are in fact poor. Rahmah is not anti-"Chinese" in her sentiments. But she is confident she is not "Chinese" not only because she does not look "Chinese" (many "Chinese" are indistinguishable from other Indonesians and some pribumi look "Chinese") but also because she knows she is not made of wealth, whereas "Chinese" are somehow inherently so fabricated. Exactly the same confusion of appearance and property arose in other pribumi I spoke with who were afraid that they did, in fact, "look "Chinese," that is, look wealthy, and that therefore they might be subject to looting, as though wealth were a physical and therefore a racial trait.

But Rahmah also identifies herself with the victims of the riot. It is again a question of class. She is not rich, but neither are most "Chinese." Certainly the owners of the small shops she watched being robbed were not wealthy. But it is not because she is realistic about the actual wealth of "Chinese" that she is able to find something in common with them. She is not threatened by their wealth because she knows that she can guard herself against wanting it. She said of the looters that they were "spontaneous" in their actions once given the example of other looters; that, in view of their restraint for so long, once it was all "free" (gratis) they could not resist. She grants

12 Chinese from China, I am told, find those called "Chinese" in Indonesia indistinguishable from other Indonesians and lacking, therefore, in whatever characteristics make one Chinese according to Chinese. "Chinese," then, the term for those so called in Indonesia, is not a matter of inherent characterisitics but, particularly given their long history in the archipelago and consequent intermarriage, an aribtrary linguistic practice. For this reason I put the term in quotes. 
to the "Chinese" what she grants to herself; the ability to resist the lure of (imagined) wealth. This leaves the word "Chinese" or "Cina" in her parlance, ambiguous. They are other than she insofar as they are wealthy. They are the same as she insofar as they are "human beings," that is, trained, educated, able to resist the immediate availability of wealth, real or imagined; both are, in fact, middle class.

Some looters were themselves not much different from her. Here is a letter to a columnist in an Islamic magazine which publishes advice to its readers:

On May $14^{\text {th }}$ I nearly joined the looters. Maybe because of the influence of the masses, I lifted a twenty-inch television set in an electronics store. As a matter of fact, for a long time I wanted to change my television, fourteen-inches [for a bigger one]. But suddenly, both hands and feet started to tremble. I thought of God. "Ya, Allah, how can I take the responsibility for this?" Then I set the thing down again and asked God's forgiveness. Ustadz, is what I did a sin? Can this sin be forgiven by asking forgiveness? Do I have to ask forgiveness from the store owner? ARH (Bekasi). ${ }^{13}$

The writer of this letter acknowledges thinking that he too can do what the people around him are doing: take goods. He is influenced by their example. But that is not enough. He thinks of what it is that he has wanted "for a long time." The writer recalls that "for a long time" he wanted a bigger television set; his own is merely "fourteeninches." There in the shop broken open just in front of him he recognizes what he has long thought about, a twenty-inch set. There is, here, no question of need, as there is in the usual discourse of why looters looted or "the people" acted. It is simply a question of finding what he has long awaited. Even were he not poor (there is nothing to say that he is, in fact) he would still loot, at least to the extent that he did so on May 14. What we see is that Rahman's description implicitly fit the looters, at least if this man is typical; they were perhaps in need, but certainly desirous. They had seen what "others" had. The others on television were not "Chinese." But magically transported by the synapses in operation in times of anti-"Chinese" riots, the television that had once been seen, perhaps, on a soap opera, appears now in the possession of "Chinese," which means it is available; available with them and not with others.

The widespread statement of the need of the poor conceals the opening of desire as it is fostered in the market: on television and, as it were, through the television set. The defense against this desire, the ability to keep it in control, is the ability to consume moderately. To think of God as one lifts someone else's property, to set their property down again, is to put desire in touch with a source of restraint. ${ }^{14}$ By contrast to say "Chinese" as the woman lifting a sack of rice did in defense of her actions is to make "Chinese" the mere equivalent of "riches." It is a word that for some at a certain moment blotted out other thoughts; but, in the next days as in the previous ones, fell back into its everyday sense.

13 "Nyaris Berdosa" [Almost Sinned], Panji Masyarakat, July 1, 1998, p. 52

14 The restraint here is religious but that is only one of its modes. In this case, the religious expert to whom he addressed his letter advised him he need not ask pardon of the Chinese and he need make no further religious efforts to be free of sin since, by putting the set down, he had stopped before he had transgressed. In the light of the diverse places Islam took in the riots, it is interesting to see the legalistic 
Something snaps into place in the immediate present, a wish that until then, "for a long time," had been realized only by someone else someplace else. We are not sure that this man or others "for a long time" wanted what they at least attempted to take. It may be that when seeing the television set, in the way of ordinary shoppers in a mall, this man looked on something he'd never thought of wanting at all, but, somehow, in the moment of seeing it, he thought he'd always wanted and even needed it. Viewed in the soap operas, on tv, the twenty-inch television set is a theatrical prop rather than private property. In the context of the riot, the twenty-inch set stood out amongst the goods visible through the open facade of a shop. It was-according to his testimonyhis wish about to come true. The abrupt realization that he could have his wish comes with the word "Cina." The word was the means by which an element of scenery changed its setting, moving out of the theater but not out of a theatrical or imaginary realm. Its new setting was "Chinese" meaning at that instant: "what I have been wishing for," "wealth" and "here waiting for me."

It is quite likely that the woman carrying off the sack of rice buys her daily rice from the same merchant. She is likely also to have had cordial relations with him and to have such again in the future when her present supply of rice runs out. What distinguishes her from Rahmah and the middle-class people who refuse to loot is not only respect for property or its lack. It is her inability to put the word "Cina" - "Chink" might be its English equivalent-in its pejorative and magical sense in touch with the person with whom they deal daily.

The condition for their thinking is precisely unlike the condition of the trembling letter writer. They do not see catastrophe looming before them should they give in to what the word "Cina" means: "what I now know I wanted for a long time, which is available in front of me at this moment." No disaster threatens. They are not transformed in their identity, suddenly becoming criminals or sinners, contaminating their sense of being good Indonesians. And the next day or the next month the store and its owner will be there again. Catastrophe, they feel, threatens neither them nor their victims.

Indonesian culture at present is racist, but Indonesians are not racist in the same manner as Europeans. The ease with which Indonesians ward off catastrophe distinguishes them from the latter. European racists find the presence of Arabs or Jews or Africans or Turks intolerable because, it seems, they embody elements of themselves they cannot bear and which threaten disaster. This intolerable other seems constantly present; it becomes necessary to expel it or, I should say, "them." Those Indonesians bothered by "Chinese" have a different complaint. It is not that "Chinese" should leave Indonesia, but that they should become better Indonesians. The current form of this says that "Chinese" should introspeksi, that is, meditate on their failure to mix with pribumi, meditate on their own intolerance, which takes the form of promoting their own kind in their banks and big enterprises over worthy pribumi. ${ }^{15}$

emphasis on property rather than an ethical response about those of other religions, violence, and so forth in this answer. For instance, there is no mention of "Chinese" in his answer.

15 For an example in English of this commonly expressed attitude, see the letter to the editor of the Jakarta Post by S. Sastrowardojo of May 30, 1998. 
86 James T. Siegel

Until Habibie became president, non-Javanese often remarked that only a Javanese could be president and that Javanese are favored in the government bureaucracy. Indeed, Indonesian firms are sometimes segregated, with certain taxi companies employing almost none but Javanese, others no Javanese. Such segregation is not thought comparable to the kind of segregation practiced by the "Chinese." When the pribumi favor one ethnic group over another this does not raise fears or charges of separatism. The same behavior by "Chinese" makes pribumi sometimes feel that "Chinese" will not or cannot or do not want to become "true" Indonesians.

Of course, anti-Semites claim Jews are clannish and keep to themselves. But a racism that not only levels charges of exclusivism but that claims to want to remedy it by inclusion requires another kind of thinking than that we apply to the European variety. ${ }^{16}$ It means that "Chinese" are not in the place of the consolidated, insupportable other, constant bearer of all that threatens lethal contamination, tolerated at best and then only provisionally. In other words, though they may be stolen from, murdered, raped and be the victims of arson from time to time, they are not hated. But they remain outside the capacity of many pribumi to accept them comfortably and from time to time they snap into the place of the intolerable, this intolerable being uncontrollable desire.

There is a relation between class, race, and national identity in Jakarta that keeps racism under control, albeit imperfectly. In the stories of the riots, the "Chinese," as I have said, are sometimes blamed for starting the riots simply by being who they are in Indonesian society. But the real danger in these stories is, indeed, not the "Chinese" at all but those who are unable to keep themselves from looting. The anti-"Chinese" riots I am familiar with from Java usually begin abruptly and end the same way. ${ }^{17}$ As they go on, they evoke uneasiness in many who are not "Chinese," in part out of fear that they themselves will be next should the riots exceed their original targets. It is usually at that point that the riots cease. The danger of disorder arising from below, the danger of the massa, is greater than that of "Chinese" who are only the lure that attracts the massa and sets them on their riotous path. Catastrophe might come from the underclass, but the double view of them-as massa, therefore a source of catastrophe and as rakyat, the people, part of the nation-keeps catastrophe out of mind most of the time.

It is a question of how the relation between the two terms is managed. The assumption, as we will see, is that "the people" need to be educated, an idea perhaps as old as Indonesian nationalism. It is the job of the government and the enlightened class as a whole to do so. In this notion there is already the idea of a "gap." Following Benedict Anderson, I believe there was already a fear of the underclass during the revolution with the stifling of a social revolution. ${ }^{18}$ This fear was identified as a "gap" (kesenjangan) between the people and the well-to-do during the New Order when not

\footnotetext{
${ }^{16}$ Further analysis of the assertion that "Chinese" fail to mix with their neighbors can be found in Siegel, "Kiblat and the Mediatic Jew," forthcoming in a volume edited by S. Weber and H. de Vries.

17 On the trajectory of such riots see James T. Siegel, Solo in the New Order: Language and Hierarchy in an Indonesian City (Princeton: Princeton University Press, 1986). The riots of Jakarta are unlike those of Solo in 1980 in that the rioters were not the massa but students. The underlying assumptions about wealth and "Chinese" were the same however.
}

${ }^{18}$ B. R. O'G. Anderson, Java in a Time of Reoolution (Ithaca: Cornell University Press, 1965). 
merely "Chinese" but other Indonesians began to grow wealthier. The use of the word "gap" is practically coterminous with the existence of a middle class on a large scale. It is usually spoken of as a difference between "Chinese," who are wealthy, and the underclass, who are poor. If there is disorder it is in the first place said to be because the underclass is tempted by the wealth of "Chinese," as we have seen. The wealth of the non-"Chinese" middle class is thus obscured or denied.

The difference between classes can be managed when desire for wealth can be controlled. The insistence that "Chinese" are wealthy and therefore we, the rest of the middle class, are not, shows the ambiguity of middle-class identifications. They too feel the threat of their impulses, and they know as well that from the point of view of the underclass they are a target. They need not have a lot to feel vulnerable; they need only have somewhere within them the same notion of riches, a notion which, of course, the New Order fostered in both official policies of Development and in allowing the enormous development of consumerism. To fear the massa is to displace their own interior menace.

One recourse is to blame the government for allowing such a gap to develop, thereby giving "Chinese" too great a place in the economy, and to hope also that the government will keep order. If disruption does occur, there is another source of reassurance. Often not long after public disorder, rumors and speculations about the instigators of the events circulate among people, particularly in Jakarta. Always someone in the government, particularly in the military, is thought to have provoked the actions. The reasons adduced for the riots include allowing the massa to attack Chinese as a diversion from political difficulties. But the major effect is to show the need for government control. Thus it is widely believed that Suharto, in Egypt on May 13 , ordered the actions of that day and the next in order to demonstrate the need for his own sake and perhaps to justify instituting military law. The other person widely accused was Suharto's son-in-law, Lt. General Prabowo, who was said either to have acted on behalf of Suharto or, in another version, in his own behalf in an attempt to gain power. Neither story has been confirmed at the moment I write this. In June, however, as I have mentioned, there were many rumors of men with military bearing, wearing boots, arriving in trucks on the scene where riots were to take place, then summoning the crowd and inciting them to looting. These rumors emerged in the press by the end of June and early July.

The educated classes found the question of who exactly ordered the riots to be a matter of much interest. The tone of these conversations was likely to be similar no matter who engaged in them. The events were shocking. It was a serious matter but at the same time, discussion of "who was behind it" generated a degree of satisfaction that initially seems inappropriate, given the shocking quality of the events. The general conversation in the press about the place of the "Chinese" had the same quality. One felt that the writers, shocked though they were, were pleased to be able to deal with a matter of such importance. The satisfied tone is not incompatible with an appreciation of the brutality of the events. Once the events are thought to have been manipulated by high authorities, people understand that, in fact, the situation, no matter how violent, is under control. There is no need to fear that the massa are out of control. Furthermore to know, if that is the correct verb in this instance, who behind the scenes was responsible is to feel connected with that political backstage. The satisfaction comes, 
ultimately, from feeling that one shares in the workings of power. One knows someone who knows someone who knows who did it. The assumption, of course, is that those in power demonstrate their position by control of those otherwise dangerously violent, namely, the massa. ${ }^{19}$

Moving down the social scale, one encounters less interest in and less gossip about who did it. But people with whom I spoke still held to the conviction that the events were manipulated. Such people may or may not claim that "Chinese" are at fault because they refuse to integrate themselves, that "Chinese" are overly concerned with money, and so on. But they often say that the riots were a mistake since the result was to put more people out of work. In the end, though many such persons told me how they were barely managing to earn enough to feed themselves, they showed little uneasiness. In their case too, the sense that, ultimately, things were under control even if mistakes had been made remained strong-strong enough to assuage fears that the economy was out of control and that they would be its victims. ${ }^{20}$

By far the most common opinion was that the events were manipulated, hence controlled. The other possibility, that the massa acted "spontaneously," however, could also lead to a similar feeling of personal safety, even, as we have seen, for a young woman walking home in the midst of looting. The "Chinese" with whom I spoke also believed the events to have been manipulated. I met sixteen people who had lost everything or nearly everything. Their houses had been looted and sometimes burned. Their real estate was worth nothing. In some cases, they had also lost shops and cars. They were living with relatives. They were, in fact, internal refugees. Many of these people were understandably angry. They were angry, however, not so much with the rioters themselves as with the authorities. Some told me of having given large amounts of food to people in the neighboring slums to help them through the crisis before the rioting. Then, as one said, "Just look what they did." But this person spoke not so much in anger as with irony and patience. He pointed to the anti-Chinese slogans painted on his house. He certainly was not pleased with them. There were some people squatting on the curb a little way off as he spoke. I asked him if they were likely to have been amongst the looters. He said he thought so, but he seemed quite neutral. Then he went on to tell me something often heard: how when the riots began he and others first called the police and then various army officials. No one, however, came to help them. They were left to flee with their families and servants to a nearby golf course where they were safe. In his view, his impoverished pribumi neighbors were not

19 On the structure of Indonesian political gossip, see "I Wasn't There But...': Gossip and Politics in Jakarta," Archipel 46 (1993): 46-59.

20 The same logic governs the question of bringing Suharto to trial. The authoritative exposure of the Suharto family wealth in journals such as Forbes, which listed him amongst the richest people in the world, convinced people of what they already knew. Most people I spoke with think Suharto is a crook, but the sense that, even in the midst of disorder, in fact particularly in the midst of disorder, there is control makes them patient. They do not want to risk the disorder they feel would eventuate if there were strong calls to bring Suharto to justice. Even Suharto's brutality becomes an asset to him because it indicates his strength, determination, and control, which people are not certain has been permanently contained. The reluctance, surprising to me, to hang him by his heels, shows his murderous qualities to be a valued part of Indonesian political life in the past and perceives it as a menacing force in the present and therefore not to be disturbed. This could change as demands to reopen questions of responsibility for the Tandjong Priok massacre and the killings in Aceh, in particular, made by Islamic elements, become louder. 
at all admirable. But his anger was largely reserved for the police, the army, and for those he was convinced had allowed these people to act. He had no doubt at all that the riot was instigated. He felt entitled to government protection (and he had given money to the police for that purpose). It was unjust that he had been robbed. He worked hard for his money; he got up daily at five o'clock, he returned home from work after dark, he worked weekends. He deserved what he had. But his fury was reserved not, as I have said, for those who left his house absolutely empty but for the authorities who should have stopped them and who were in fact themselves responsible for the disorder. They should have acted differently and, he assumed, they would act properly at some other time in the future. His anger, in other words, was based on an assumption that he had and has a right to protection and that he was not only justified in asserting that right but that he would prevail, at least sometimes.

The man just cited was the angriest "Chinese" I met. Others, who had lost as much, were certainly perturbed, but less upset. At Pasar Glodok, men who had lost their entire businesses told me that their creditors would understand and not demand payment for the goods they had on loan. It was understood that later, when the market was rebuilt and they reopened their businesses, they would get more goods on credit. Their standing protected them. These men also blamed the government for lack of protection. Like the others, they too had no doubt that they merited protection, not merely on human grounds but because they had been born in Indonesia, they were citizens, they lived honestly. Not to have the protection of the government was outrageous. Such an attitude implies that their rights and the possibility of invoking them have not evaporated entirely. They too felt a connection to the government; they too had their own access to it. They told me that they indeed paid elements in the police and the army to ensure they were protected. ${ }^{21}$ The fact that the people they had paid failed to respond when they were needed and summoned increased their anger. But at the same time, they knew that they had the right to protection, and they retained the expectation that they would be protected again. In the end, one has to say that they were exasperated. Some, families with rape victims or members afraid of suffering sexual violence indeed left the country. They were like refugees during World War II, certain they were the constant target of hatred their lives in unceasing danger, simply because of who they were by birth; but most did not feel this way. These "Chinese" could make themselves known to political authorities and certainly planned to do so again. They too believed it was a good thing for "Chinese" to integrate into the nation and the local community and felt that integration was already the overriding reality.

The assumption behind the logic just outlined is that Indonesian society can always contain its elements. None of them are by nature a source of irreparable rupture, neither "Chinese" nor the underclass. In this view, society may be composed of groups or individuals, each with its own characteristics, but in addition there is a correct way to behave, "custom" or adat, right manners, which is common to all and, as the idea has evolved out of assumptions originating in the regions, national in its scope and definition. No matter who someone is, there is a proper way of speaking that allows one to include that person. Social discourse in that sense is perfect; its breakdown can

\footnotetext{
21 The police sometimes responded. Jakarta is the site of the world's largest vihara (Buddhist monastery). Henri Chambert-Loir and I were told that it was filled during the riots by people taking refuge there and that it was safe. The local police post had been called and sent men; they were paid for their efforts.
} 
only come from those who are as yet ignorant of its rules. These people, the rakyat, are in the process of development; the educated classes will see to it that they learn; in the meantime they will be controlled, one hopes, by those in power. Thus "Chinese," though they might offer too tempting a target for those who do not understand how to control themselves, are not an inherent threat to national society because those who have not yet learned control are controlled by others. The foundation of social order is ideas of right behavior applicable to all; in case of their failure, there is governmental authority.

I have never heard an Indonesian admit that his or her national society is inherently flawed by racism and that certain groups or individuals are intolerable. The experience of the former Communist political prisoners and their descendants still surveyed and discriminated against not withstanding, Indonesians continue to hold on to their assumption that all peoples of the nation belong there. In the case of "Chinese" this assumption is put into doubt, but not given up. There is an unresolved contradiction. On the one hand, proper behavior forbids exclusion; on the other, "Chinese" are sometimes improper not by behavior but by identity.

The result is embarrassment. At the beginning of the New Order, "Cina" (Chinese) was a word of contempt which the government forced into use. The respectful term till recently rarely heard was "Tionghwa." The embarrassment caused by "Cina" for Indonesians is indicated by the series of euphemisms that followed, including "WNI," meaning "Indonesian citizen," used only for "Chinese," and most recently "keturunan," meaning WNI keturunan Cina, "Indonesian citizens of 'Chinese' descent," as though one indicates one's delicacy by pointing to "Chinese" as (also?) citizens or people with ancestors. Many "Chinese" are likely to evade the problem by using the English term "Chinese," while retaining, for instance, the term "Tiongkok" for "China." These linguistic vagaries show that the subject of these terms figures as something Indonesians want to turn away from. But there is also linguistic evidence to the contrary in the use of "Cina." After decades of use, for some, particularly younger people, both Indonesian and "Chinese," the word is no longer pejorative. The necessity to include everyone in discourse and long usage have neutralized the term for certain people.

There is a more sinister version of the same theme. "Chinese" have a special code on their identity cards, thus exposing them even if, as most have, they no longer use Chinese names. It is as though assimilation must be denied. The fact is that "Chinese" have been assimilated in every way except that they are not fully accepted. The embarrassment the terms for "Chinese" evoke is not caused by anything inherent to "Chinese" themselves but by the prejudice against them rubbing against the Indonesians' characteristic refusal to think that people who behave well can be excluded.

Indonesians make trouble for themselves. When they point to the preferred place of "Chinese" in colonial times, or charge that not all "Chinese" took part in the revolution, as is still sometimes done, or complain about "Chinese" pay-offs of government officials, they act in bad faith. Other Indonesian groups also enjoyed preferred status under the Dutch and even fought alongside them, yet they are not targeted. And probably most Indonesians pay bribes when they find it necessary to get official permits. The tendency to associate "Chinese" with wealth, as we have seen, is 
at the heart of Indonesian difficulties. One might argue that in peasant societies there is somehow a necessary friction between those who deal in money and those who think in other terms. If there is, it applies in societies where money exchange is limited. Life in Jakarta, even for its large number of immigrants from the countryside, involves money transactions with a range of people, not merely "Chinese." It is not only "Chinese" who should be the target if actual money dealings were the cause of resentment. Furthermore many non-"Chinese" Indonesians are wealthy. Many are traders, some are hugely wealthy, but none have their nationality discounted. Thus to point to an historic association of "Chinese" with wealth as the source of prejudice or to the character of a society clinging to peasant qualities without asking why such prejudice is limited to one segment of the population is to glide over the fact of prejudice. This becomes evident when one notices the call for "Chinese" to return from abroad after the riots because, amongst other reasons no doubt, their money is needed. Or the commonly expressed idea, held even by those who resent "Chinese," that the riots were a mistake because the destruction of businesses meant loss of jobs. Real wealth gives "Chinese" a place; figurative wealth leads to riots.

One can reasonably say that New Order Indonesia has been invaded by the market in many forms and that this has caused difficulties. But the problem is more general. It is not commodity exchange as opposed to other forms of circulation that gives rise to the difficulty. The assumptions of Indonesian national society are pinched not necessarily by their traditionalist residue but by the terms of emancipation from tradition and colonialism which guaranteed that modern Indonesian society would also always be moral, in contrast to both the backwardness of older prenationalist generations and the immorality of Europeans. ${ }^{22}$ This left no place for the autonomous workings of desire, which is to say, no place for the disruptions internal to the person, so easily aroused in a society where the market dominates; in other places such dislocations are simply expected. Indonesian discrimination springs from the energies interior to the nation which it cannot account for and which it attributes to "Chinese." Had Indonesian thinking about desire evolved during the New Order, the fears that came with heightened desire might have been alleviated. Perhaps anxiety of this sort can never be stilled. But it is a grave fault of Indonesian culture and intellectual life that it is expressed through violence and prejudice. ${ }^{23}$

\section{Rape}

The balance between racist and assimilationist thinking, the paradoxical reassurance or perhaps denial which followed the riots was shaken, however, when stories of rape began to circulate a few weeks after the events. Reports first reached the "Chinese" community, so far as I can tell, and then spread throughout Jakarta. They then emerged in the press; first and most extensively in the English language Jakarta

\footnotetext{
22 On this topic, see James T. Siegel, A New Criminal Type in Jakarta: Counter-Revolution Today (Durham: Duke University Press, 1998), and James T. Siegel, Fetish, Recognition, Reoolution (Princeton: Princeton University Press, 1997).

23 On the relation between violence and identity see Hent de Vries and Samuel Weber, eds., Violence, Identity and Self-Determination (Stanford: Stanford University Press, 1997), particularly the articles by de Vries, Weber, and Derrida.
} 
Post, and then in the major papers and magazines. These were stories both of rape and molestation of women. The second concerned "Chinese" women trying to return home, being stopped, dragged out of their cars or off their motorbikes, forced to undress in front of a gang of men and ridiculed, but not always raped. Often in these stories an older man from the neighborhood or a taxi driver showed up and led the woman away. In other stories, which came to predominate, women were gang raped. These stories emerged gradually. It also turned out that some women were burned to death as their apartments were set afire after they were raped, that some later committed suicide, and many fled to Singapore or Australia.

There is no doubt about the depth of feeling these stories evoked. Anti-"Chinese" activities have been known since the beginning of the republic and, in fact, before. ${ }^{24}$ But anti-"Chinese" sentiment has evolved in recent decades and stories of rape were new. In June 1998, these stories evoked genuine outrage and shame in every person with whom I spoke, no matter from what class or religion or sex. ${ }^{25}$ When Indonesians, "Chinese" or not, told me the stories, there was invariably a break from whatever we had been speaking of earlier. The somewhat pious tone of disapproval in which stories of looting were usually told gave way to uncertainty not about the facts but about what to say about them or, I felt, how to speak at all.

Press accounts varied in tone. Rarely were these written in the first-person. Most were taken from the meetings of the Human Rights Commission at which family members testified to the experience of their wives and daughters. Some stories were told over the telephone by victims who had fled the country. Many accounts came from the victims via the women's groups which counseled them after their terrible experiences.

The reports show that the reporters were shaken. Here is an example:

A young woman, call her Joana, twenty-five-years old. The young mother of an eight-month-old child never imagined that the place she lived, Cinere, South Jakarta, would be the target of rioters, much less that she would be the victim of rape by savage humans.

In the blink of an eye her house, neatly arranged and cleaned, was in complete disorder. The glass was smashed. Her things were all taken out. Joanna and her husband were in a panic [panik]. They screamed for help. Useless. Their voices were lost in the tumult of the massa.

\footnotetext{
24 On the connection between anti-Sinicism and Indonesian nationalism, see Takashi Shiraishi, "AntiSinicism in Java's New Order," in Essential Outsiders: Chinese and Jews in the Modern Transformation of Southeast Asia and Central Europe, ed. Daniel Chirot and Anthony Reid (Seattle and London: University of Washington Press, 1997).

25 By the end of June these stories too were taken up into the discourse of manipulative, therefore ultimately reassuring, power. It was said that the rapes too were instigated. In the meantime, the police said that they had no report of rapes; General Wiranto, Minister of Defense and head of the armed forces, was rumored to have told women's groups that the rapes may not have occurred. The Minister for Women's Affairs first said she could do nothing since there had been no official reports of rapes; then, under pressure from women's groups, she set up a hot line for complaints which, gossip had it, were mainly directed against her lack of action. The entanglement of the stories in questions of administration did not lead to the abatement of descriptions in the press, however. These reports were in no way prurient; they demonstrated the widespread feeling of shame and of identification with the victims of these attacks.
} 
Carrying their little one, her husband tried to save himself and looked for a safe place. Unfortunately for Joana, she was not allowed to get away. Someone grabbed her arm and pulled her out of the room. Joana's husband was not able to help. While others were busy looting, someone unknown tried to let loose his cruelty by staining Joana. Joana was pushed outside by several people before she was raped by one after the other. Her screams of pain went unnoticed.

At that moment the light of Joana's life went out. There is not a drop of happiness left in her life. She is in trauma. Shock [in italics and English] has flooded her life. ... Though the doctor has allowed her to go home, her friends still testify that Joana is gloomy and abstracted. Occasionally her face will show the depths of her sadness. In fact, she once wept and wept, lamenting her fate. Actually Joana is reluctant to see her husband. There are only a few people she will see. ...

For Joana what she experienced is a stain, a shame [aib] which cannot be forgiven, but has to be obliterated. So that her descendants after her will not be ashamed.

The bitterness Joana is going through is not only the bitterness of Chinese women, but of women in general. 26

The language of this piece might make the reader of English suspect a certain lack of directness of feeling. It is, indeed, the case that not all rape accounts have this tone. The use of such language, particularly in a magazine whose reporting is usually far more direct and even "hard-hitting," indicates the difficulty of knowing how to speak of rape or perhaps of sexuality. Indeed, the only time rape was likely to be reported at all before the riots was in the popular newspaper Pos Kota, generally looked down upon by the middle class as sensationalist.

To speak of the "light going out from Joana's life," for instance, recalls the language of the Malay classics. It indicates respectfulness and the need to have recourse to language quite different than the spoken language or the usual lexicon of reporting. To begin the description of what happened to her by calling the agent "someone unknown" might reproduce what Joana saw as her attacker approached. To continue by saying "someone unknown tried to let loose his cruelty by staining Joana" is to veer away from the event into a standardized language of euphemism and moral condemnation. It is also to apply an Arabic word, aib, (stain) to the "Chinese" woman. With rape, a certain universalism applies. But whether it is because the theological term comprises all women, Muslim or not, or, because the rapists were Muslim, the stain itself becoming a mark of a corrupted Islam, I cannot say.

At the moment of rape the word I have here translated as "savage," biadab, occurs. This word moves the account away from the woman's experience into an understanding of the place of savagery in a general explanation of Indonesian culture. The standard dictionary of Indonesian translates "biadab" this way:

1. belum beradab; not yet polite belum maju kebudayaan; not yet culturally developed.

2. tidak tahu adat (sopan santun); kurang ajar; anak itu benar, tidak segan mengucupakan kata kata kotor di hadapan umum. Without knowledge of custom

26 "Kisah getir amoy-amoy korban perkosaan," Aksi, June 16-22, 1998, pp. 4-5. 
94 James T. Siegel

(politeness); uneducated; that child really doesn't hesitate at all to say dirty words in public.

3. tidak beradab; kejam; pemerkosan anak di bawah umur adalah perbuatan yg biadab. Without politeness; cruel; the rape of minor children is savage.

I had no choice in English but to use the word "savage" because it combines the sense of "cruel" and "uncivilized." Weak in American, that connection is strongly apparent in Indonesian. Not to be courteous, not to know how to behave with manners, means also, in Indonesian, to behave "savagely" in the sense that one is not yet civilized and, often, that one acts violently and belongs to a different class of beings. The almost invariable use of the word biadab to describe rape contains the implication that the rapist was savage in these senses. This, indeed, is close to the use of the word "bodoh," usually translated as "ignorant," to describe "the people" (rakyat). It is up to the leaders and those already cultured to help "the people" become courteous, that is, civilized and no longer ignorant, loutish, and unaware of civilized behavior. Such usage is not always contemptuous, merely condescending in the older sense of that term.

There is another implication of this word which is contained in the second meaning. The television commentator Wimar Witoelar, for instance, said in a written article:

I think the biggest tragedy, greater than the ruin of the economy and the political disorder is our lack of morals [budi pekerti] as a people who clearly allowed savage [impolite, biadab] behavior toward those equally human. The issue of rape and looting is much bigger than the obvious fact we have the same citizenship and is far removed from the racial friction of the Dutch East Indies and Indonesia. How could we act toward other humans in that way? How could we allow torture, rape, and murder of other humans?

In part the lack of civilized behavior is a product of corrupt and unbalanced political and economic development; in part it comes from the low morals and ignorance [kebodohan] of people who still harbor very primitive racial instincts. ${ }^{27}$

As I have said, the term "biadab" usually modified the word "rape." Looters here are biadab because they are first of all rapists. Racism apparently may be excused on historical grounds. But the morals of the rapist-looter, according to Wimar Witoelar, are inhuman; the issue is one of common humanity. Culture here, the opposite of savagery and of impoliteness, is general to humankind. On the other hand, the "we" is not "all humans" but "Indonesians." The culture involved, though it is implied to be general, is Indonesian, the national culture. The source of knowledge of proper behavior is here national. Its failure appears in the lower-class people who raped and also in the upper-class elements of the political class who allowed them to do it. "Savagery" is a characteristic of the undeveloped lower classes; the upper classes should have fostered their development and thus supervised the eradication of their savagery, or, if such has not yet been accomplished, at least kept them in place.

In effect, the writer spells out the assumptions of the word "biadab" "impolite/savage." In doing so he indicates the connection between the moral condition of the rapists and the political class. Wimar Witoelar, known as a critic of

27 “Tragedi yang Jauh Lebih Besar” [A Much Bigger Tradedy], Kontan, June 29, 1998, p. 16. 
Suharto, is clearly amongst the majority who thinks that the regime itself was responsible for the rapes, at the very least in the general sense of creating the conditions for it. Here, however, rather than there being a certain satisfaction in naming the upper-class instigator, there is outrage at both the rapists and those who allowed them to act. Biadab, as it is used here, at once evokes the brutal lack of civilization of the rioters and blames the regime. A reversal in attitudes has taken place; those who express their opinions no longer feel reassurance that "we" are safe because violence is controlled by elements of the government, but now fear that "we" are endangered because the regime, or elements of it, itself is violent. In the meantime, however, Suharto had resigned leaving the question of power ambiguous; at least some of those responsible had left office. But people suspected that they were, nonetheless, still at work. ${ }^{28}$

At stake here is not merely who started the riot but the failure of sociality itself in important segments of the population, including elements of the government and military. The assumption underlying stories about disruption was that violence was always possible, but that violence was limited to the lower class or, in the worst case, to elements in the government who borrowed their ferocity from elements they then control, as happened, for instance, in the murders of presumed criminals in the $1980 \mathrm{~s}^{29}$ In that instance, Suharto ordered killings without trials, carried out by soldiers in mufti. Corpses were distributed on city streets. The government thus appropriated the power of criminality for itself. Most Indonesians seemed grateful for the suppression of these supposed criminals. In the violence of 1998 in Jakarta, however, the government, or at least the army, appears tinged with a criminality which is of no use to it. Its orchestrated appearances with crowbars in hand did not aid in keeping order. The only understood result was revolt. When Wimar Witoelar uses "we," he generalizes condemnation to the point where "we Indonesians" are culpable and thus puts in doubt the very foundation of social behavior.

There is another feature of these stories of rape. The victims were described as members of families. It would be possible to tell the stories differently. Reporters who described women traveling alone who were stopped on the highway and pulled from their cars could have finished their portraits without mention of the victims' husbands, fathers, children, and mothers. The feelings of wonder and revulsion the rape stories elicited were linked to seeing these victims as daughters and mothers. The paths of identification thus led to them and not to their violators.

These stories, told for the first time and told as they were, were impossible or at least difficult to recuperate for the usual political purposes. For that to happen,

\footnotetext{
${ }^{28}$ No doubt partly because it is now safe to do so, the press has brought up incidents from the New Order's past, such as the killing of rioters in Tandjong Priok, the port of Jakarta in 1984, asking for the truth about the numbers killed. It was partly also out of fear that the elements in the armed forces thought responsible for the recent riots were still at work even if the same people were not involved. The rioters of Tandjong Priok were Muslims, and it is Muslim groups who asked that the case be reopened. It is not interest in this case alone which has been revived. See, for example, the cases reported under the title "Saat Kita Berterus-terang" [Time to come out with it], D\&R, June 27, 1998, pp. 15-30 and "Gerakan Politik Jenderal Benny, "Panji Masyarakat, June 17, 1998, pp. 15-22. As of the time of writing, it is also clear that the Habibie regime and some Islamic groups want to deny the rapes, the former to protect whoever was responsible and the latter to avoid taking the blame for the massa being Muslim.

29 On this topic, see Siegel, A New Criminal Type in Jakarta.
} 
disruption has to be thought controlled from above and there has to be confidence in such control. But the conditions that would allow the usual cycles of aggression and accommodation to take place-so that "Chinese" would become targets, then anti"Chinese" sentiment would evaporate and everyday business would continue without much trouble later-did not pertain in the cases of rape. The word used time after time was "trauma," from the English, to mean that the effects of rape would not disappear. The "stain," (aib) in the old-fashioned Arabic vocabulary used to speak of the act, was just that. It was a mark of the massa which would not go away. Stories followed of disease, suicide, pregnancy, depression, and broken family lives. Given this new public understanding, the reconversion of "massa" into "the people" (rakyat) must become more difficult. The notion of rakyat implies its complement, "leaders." When the unconscious sliding between massa and rakyat is more difficult, leadership is also put in doubt. The idea that later, and not much later, normality will restore itself was thus also put in question. The lack of confidence in Habibie, Suharto's successor, was due to this as well as many other reasons.

If the rapists were not defined as people controlled from the top, but as autonomous actors, then their acts, widely shared in, witnessed, and transmitted from mouth to mouth, would be an assertion of the power of the massa, a power used to upset basic tenets of behavior. Rape could then be a revolutionary deed whose target would be the middle class. The state itself along with middle-class society would be threatened. This possibility remains latent. Rape reinflected political discourse, but as an element in the call for "reformasi." Indonesia's only successful revolution was anticolonial, not civil; the potential for a civil revolution remained inherent in the events of May. Whether such a revolt might be incited from the top or not becomes less important at this point, since a vision of widespread civil unrest prompts people to realize that no one can insure control from the top must always work, and since the need to control the massa of course implies that they are always a threat. But in the end, the idea that the rapes were instigated by the government meant again that they were under control. That control, terrible as it was in its exercise, and even thought to be directed against "us," the middle class, was preferable to the "spontaneous" act of the savage-and therefore potentially revolutionary-massa. The rakyat has only the aims of its leaders; the massa have their own impulses and these can only be feared.

Rape was placed in a political discourse centering on the question of its control but with a second dimension, "trauma," which further reinflected political discourse. ${ }^{30}$ The idea of an unforgettable experience with effects which, we will see, transcend those of the sufferer, comes with descriptions of victims' experiences (as opposed to mere use of the word "rape"). These were rarely written in the first-person since the victims cannot or are reluctant to speak. Here is an exception published in a woman's tabloid:

Really I don't want to tell anyone about this shame. Life has no meaning for me all the more so since my boyfriend no longer sees me. He seems to be disgusted.

${ }^{30}$ The word "trauma" in English, or as an English word adopted by Indonesian, was used to describe the suffering of the rape victims. "Trauma" is a fairly new term in Indonesia, used commonly only well after the commencement of the New Order. On the introduction and use of this term see Siegel, A New Criminal Type in Jakarta, Chapter 4. 
But, okay, I will start this story on the $6^{\text {th }}$ floor of my office building at 10:30 am (Thursday, May 14) when I saw Jakarta thick with smoke.

Many nearby buildings were on fire. I quick got my things together and phoned home. My servant told me that in Pluit where I live it was still quiet.

As soon as I got out of the office in the area of M. H. Thamrin [Street; a major place of international business], I raced my car north heading for the toll road in front of the Metropolitan Police. It turned out there were no toll collectors so I didn't pay anything. I kept racing on north and got out at Jembatan Tiga [in one of the major older Chinese quarters] because I saw smoke coming from Pluit. I turned onto Jl. Bandengan Utara.

But from behind the steering wheel I saw the massa hurling things at the buildings. The glass was shattered and along the street you could see lots of groups of people carrying all sorts of goods. It felt like customers could suddenly buy everything cheap.

Without being aware of it all of a sudden my car was near this swarm. Some of them saw me and yelled out, "Cina! Get Out!" I was scared to death and couldn't drive the car because in front the massa blocked it with wood and metal.

I stopped the car. This massa then threw things at it and struck it with metal and wood. The glass in front and back shattered. Feeling really afraid I then got out and asked them for mercy.

As soon as I started to move, several people pushed me. Someone took my purse with a handphone in it and about Rp. 2,000,000. The massa then got at the accessories in the car like the tape recorder, a doll and so on. I said to them, "Take it all, but just don't burn the car."

Because I gave an order, someone hit me. Others of the massa did the same. Then they took my jacket off. Then a whole lot of them pulled off the rest of my clothes.

I was forced to stay on the side [of the road] in front of the car by the massa. At the time I was only wearing a bra and underpants. A group of them pulled off my red blouse and short blue skirt and the office uniform jacket. I cried and asked for mercy but they paid no attention and they savagely attacked me.

Before that, while I was still conscious, several big men pulled me by the legs and one after the other they raped me. After that I lost consciousness.

I only regained consciousness when an ambulance came and several attendants lifted me up from the side of the street. My body was without clothes and covered with paint. I had a chance to see the carcass of the office car. Burned and shapeless.

The attendants brought me to the hospital. My body was weak and my private parts hurt.

I was cared for for a week in the private hospital on Jl. Pangeran Jayakarta. I was really traumatized and even now I see it in front of me.

My boyfriend who knows what happened wept several times. On the day it happened he called me several times on the handphone but a man answered. Then he hung up. I am sure that the guy was the one who looted my telephone.

I had been going with my boyfriend for six months. We even planned to marry next December. Really, and I swear it, up till now I never had any physical contact. In the sense that my status [in English] before I was raped was I was still a virgin. 
98 James T. Siegel

Now I don't ask what my relationship will be. Its clear though that for a week, since I have been out of the hospital, my boyfriend hasn't gotten in touch with me or come to the house. In the meantime every day I have to take medicine and get antibiotic shots because the doctor said there are patients who went through what I did and then died of infections of the womb and reproductive system.

Fortunately my boss is paying for the medicine. He and his wife are the ones who visit me most often in the hospital.

And he is trying not to say anything about this to the other employees. And my brothers, afraid to leave the house, send their wives or servants to look after me.

In fact I don't want to be interviewed and have it in the paper. What for, what good does it do me? Its just one more burden for me. I am ashamed in front of people, especially my friends.

I also refused when some people from a Jakarta foundation said they wanted to help. Help how? I know, that foundation will get a fee [English] from the donors just as soon as I register with them.

I know that nothing can clear this up. I don't know the ones who did it; there were a lot of them. If I go to the authorities even before I make a charge my face will be on t.v.

So far as I am concerned, that isn't important. Let the Almighty God act against them for what they did. They're religious people, right? They have a God. Their God surely didn't want to see this happen. The law of karma will always work. Whoever sows the seeds, he will reap the fruit. I know that's the most just law.

I still have lots ahead of me. As a girl of twenty-six I still have lots of chances to find a better life. But not in this land where I was born.

After I get well I plan to go to Australia via New Zealand. As someone who is wrapped up in the business world, I think that for the next ten years our economy won't be stable.

But I love Indonesia, the land of my ancestors [tumpah darah saya]. My mother is of Chinese descent but my grandparents were born and raised in Bengkalis, Riau.

You have to put down that I never felt China was my land, all the more so since my grandparents were pribumi. Its true we still use ghe [Khek] but only sometimes.

In Sungai Pakning, Bengkalis Regency in Riau, our house is surrounded by pribumi immigrants. We all know each other and on certain occasions we work cooperatively outside the house. ${ }^{31}$

31 She concludes by saying she understands Riau Malay and has studied Mandarin and English. She graduated from high school in 1991, works as a secretary with a salary of Rp. 1.5 million a month and goes to university, paid for by her employer, who is in the export-import business. She lives in an apartment with a servant. "Sekerang, Pacar Saya pun Merasa Jijik: Jeritan Hati Korban Pelecehan Seks Tragedi Jakarta" [Now My Boy Friend Is Revolted: The Cry from the Heart of a Victim of Sexual Humiliation in Jakarta], Nyata, June 4, 1998, pp. 6-7.

Compared with the video tapes of testimony before the Human Rights Commission, in which the facts come out rawly and with unrestrained emotion, without forming much of a story, this newspaper 
Stories such as this one are distinguished from the earlier stories of looting and destruction, as I have noted, by being said to be unforgettable and by the irreparability of the damage done to the victims and their families. "Chinese" merchants may have lost everything including their homes. They or their families may even have died in the fires. But few insist that their loss is irreplaceable. It is assumed, as I have said, that shortly the world, including "Chinese," will return to its normal state. Rape stories, as least as published, seem always to include the word "trauma." As used in other Indonesian contexts, sometimes this word simply means "extreme effects." But here, while it means that, it also suggests something has been irretrievably lost or irreparably wounded which cannot be put out of mind. Loss of woman's honor means profound shame. Shame runs so deep that it prevents almost all social intercourse. "Actually Joana is reluctant to see her husband. There are only a few people she will see." There is not merely a rift between the woman and her violators or between "Chinese" and massa. The woman is excluded from her own family. There is nowhere to turn to repair her exclusion. What, for instance, could she do if her rapist asked forgiveness? And when the government denies or minimizes the rapes and refuses to search for their perpetrators justice is not possible. The physical consequences of rape, though sometimes severe, are usually said to be nothing compared to the lasting social and psychological wounds whose import is estrangement: estrangement from the larger society, estrangement of the woman from her own family. The wound is passed

account is already formulated. Shortly after it was published, a story, "Clara" by Seno Gumira Ajidarma, was published by the Islamic newspaper Republika (Online edition, June 26, 1998) with a similar plot. The narrator, however, is a policeman who hears the complaint of a woman telling an experience which matches the one in the report above. She tells her story in the first-person, he takes it down, but, he says, "I have to be suspicious" to be sure there is not some other purpose to her story. With this justification he forces her to describe the rape, even though she sometimes falls unconscious doing so. "I have to know what happened after your underpants were ripped off; if you don't say, what will I write in my report?" he tells her. She claims she fell unconscious when that happened and he tells her "How then can you know that you were gang raped?" and warns her not to spread the word of the rape: "Rape is hard to prove. If you are wrong you will be considered to have spread slander." As he writes, he is attracted to the woman. He starts his story saying, "Maybe I am a dog. Maybe I am pig-but I wear a uniform. You will never know who I really am." In the end, he implies he has raped her himself. He ends his story saying, "Of course I do not need to report to my superiors. Its only to myself that I tell the truth, but taken down in notes-all that is secret. So don't tell anyone."

Here one sees the ambiguous reaction that developed in some Islamic groups. Like the government, they denied, or at least implied denial, that the rapes took place on the grounds that there is no proof. In the case of Republika this is partly in defense of Habibie, partly because the rioters are considered Muslim. On the other hand the ambiguous revulsion about rape also, in my opinion, is a cause of the denial. In this story, taking the action down in notes, making a record, which is precisely what the police and the government refuse to do, is a source of arousal, thus a further excuse for denial. As though, the doubtlessly unintended implication goes, were the government to make a record of the events, they, the police, would rape some more.

Given the government's attempt to claim there were no rapes and that stories to the contrary are mere attempts to discredit Indonesia, one has to be cautious in assuming newspaper accounts are authentic. I caution the reader not of course because I am uncertain whether rape occured or not-they did and on a wide scale- but because there have been attempts, perhaps by the government, to place false stories in order to say that all stories are false. What we have in the case above, it seems to me, is an actual event put into a framework suitable for the papers and for the elaboration of stories. In other words, we have the beginning of a discourse on rape; what remains doubtful is not the sentiments expressed but the possibility that these are not the actual words of the victim. The direction in which this discourse can progress and be discredited is shown in the shrewd story published in Republika Online. 
100 James T. Siegel

down: her children are infected and so also risk estrangement. Nothing is available to cure this wound since its locus is as much in Indonesian society, in its inability to reclaim the raped woman. Forgetting, it is said, is impossible. One would have to do away with shame itself to allow the violated woman and her children to return to society. The cure itself suggests the victory of the biadab, though that is not the only possible solution. Hence the national trauma.

The fact that the woman who dared to give the story of her rape to the newspaper thinks of emigrating shows the limit of the word "trauma." Her suffering continues through the memory of the aggression against her; she cannot live any longer in Indonesian society. But she might be able to live somewhere else. This woman assesses her chances and the economic prospects of Indonesia. She will emigrate because, as she says, she still has "lots ahead" of her. "As a girl of twenty-six I still have lots of chances to find a better life." She will find her chances, "But not in this land where I was born." Rape has damaged her, but the damage is irreparable only in Indonesia.

Enough people felt as she did for there to appear advertisements in the Jakarta papers for houses in Perth, Australia. Given the absence of a tradition of exile in Indonesian culture, one sees how great a modification these riots, and in particular these rapes, have made in Indonesian culture. Indonesian national society has been shown to be unable to contain its own citizens, both the massa and those it has impressed with the mark of itself.

The sense of catastrophe, largely missing in stories of previous anti-"Chinese" riots, appears in the stories of rape. We have seen this passage:

For Joana what she experienced is a shame and a stain (aib) which cannot be forgiven, but has to be obliterated. So that her descendants after her will not be ashamed.

Shame that must be obliterated (but how?) and that nonetheless will not be forgiven is a difficult notion. The woman raped will never forgive, therefore never forget, her violator. The mark of the violation, the shame itself, which is also a stain, will be passed down to her descendants if it is not obliterated. Even when this woman has children by her husband, her children will be marked as shameful. Rape in that sense harms not only women but threatens legitimacy of descent. Even when her children know their parents and can prove they are born in wedlock, they will be shamed in the way of the illegitimate.

This dimension of trauma, the ineradicable stain, disrupting descent, making even legitimate descent shameful, returns Indonesia to an earlier era. In the formation of Indonesian nationalism, it was thought that modern ways would lead to the formation of the nation. Liberated from the constraints of parental traditionalism, Indonesians found love (cinta) linking young men and women across the hundreds of different ethnicities of the archipelago. This liberation was also a new morality, family centered, which by implicit contrast made the old ways immoral. Presidents Sukarno and Suharto's fear of being thought illegitimate reflects this effect of the formation of the nation. The menace of the ineradicable stain of rape which again refuses legitimacy to descent is the eruption of a prenational element, lodged in the fears of national culture. The trauma of rape was latent in the disintegration of the rakyat into the massa which itself brings a return to a prenationalist state. 
There is yet another element in explaining why the rape of "Chinese" women shocked the non-"Chinese" middle class. The "gap" so often referred to between the middle class and the massa, leaving the latter at best on the margin of the nation, also threatened the identity of those who profited from the country's new wealth. From the standpoint of the New Order's theory of Development, wealth should not create conflicts of identity. The economic development from which the middle class profited and expanded should be thought of as part of national development. But in the context of these new events, a context marked by the end of populist policies, a new question arises: who is the new member of the Indonesian middle class? Certainly I never heard of anyone complaining that owning a new house, a new car, fashionable clothes, was in anyway undesirable. Wealth was, at least consciously, thought to enhance those who possessed it. And yet, if one looks, for instance, at the photographs in magazines, and perhaps especially women's magazines where fashion is the subject, one sees how a problem developed. On the one hand, fashionable clothes are also considered correct, continuing a long-held assumption in Indonesian culture which stressed the propriety of expensive dress. The person of wealth was entitled to it because wealth had the ability to create propriety; this idea runs contrary to the prejudiced notions implicating "Chinese" wealth. This propriety in the days of the development of Indonesian nationalism in the 1920s and 1930s was nationalist. One sees pictures of young Indonesian men, either in Holland or in the Indies, dressed in suits and ties. Dress itself, which was costly, distinguished them from the traditionalist world. To dress up was to enter a world governed by nationalist assumptions. To put on a suit and tie was to dream of Indonesia. Now, of course, though dress is still expensive, a suit and tie suggests "business" and "bisnis," the Indonesian version, has a shady reputation.

There are other scenarios implicit in the photographs of women's fashions. Once again, fashionable dress means propriety; it means an enviable domestic life. But there is also the murkier implication of sexuality always inherent in women's fashion. So long as this meant "love" in the Indonesian sense, "cinta," in which desire always led to marriage, there is no difficulty. But in the climate of the raising of desire in the market, the incessant gossip about the mistresses of important men, the scandals about "Ecstasy," discotheques, expensive hotels and so on, this is not an assumption easy to hold on to.

If one looks at Indonesian fashion photographs, like fashion photography in other places, it often lacks background. One cannot tell where the beautifully dressed woman is to be found. The setting is, finally, the camera or the film itself. This removal from the social scene that goes with proper dress, the implication that fancy dress is not only improper but also places the wearer elsewhere-with that place unspecifiedsuggests another dimension to the "gap" of Indonesian society created by the unequal distribution of wealth. It is not only the massa who are placed on the edge of the nation, it is also the middle class. Wealth, instead of establishing social place, leads to an indistinct fantasy of affluence, the mirror of the imaginary wealth of "Chinese" in the minds of looters.

If one asks why it is that the non-"Chinese" middle class was shocked by the rapes of "Chinese" women, why they, men and women, seemed to imagine themselves in the position of these victims, one might guess that, already fearing the massa, they imagined themselves as having something shameful and desirable and improper. 
102 James T. Siegel

Unable to lean on the weakened notion of Development, the national unconscious found wealth to be as shameful and as coveted as it was an instrument of propriety. This facilitated their identification with "Chinese." Their uncertainty of ownership, of having the right to what they possessed, and the wish to protect it against the massa completed that identification.

\section{The Massa Again}

No one thinks of himself or herself as part of the massa. It is a category created by the middle class, the projection of their own shamelessness onto the underclass, added to the fear of losing what they have. The massa are only realized when the middle class finds its fears about to come true. Here is an anecdote from everyday life. I rode once in the car of a middle-level bureaucrat, a conscientious man mindful of the plight of the poor and a pious Muslim. This man was driven to work in his own car each day. We had a flat tire. As usual in Jakarta several people appeared to fix it for us. Because of the anxiety he showed when he had to step out of the closed, air-conditioned car, I could not tell whether he was paying for a service or paying for protection when he took out his money. Inasmuch as it was the latter, these men off the street were candidates for the massa and not part of the people. My friend, I am sure, could not tell himself. When violence breaks out, however, there is no doubt.

The massa embody the projections of middle-class fears. They are activated at certain moments. Had there been even the suggestion of a menace when my friend had a flat tire, the men off the street would have been bad types, but they would not yet constitute the massa since the massa are always numerous. The massa in May 1998 was formed, if one can believe the accounts one hears, from above. Local men and boys had to be instructed to break into shops and they had to be taught how to rape. Later, after the major incidents were over, the following document was distributed in various Indonesian cities and over the internet. Though it dates from after the events, it gives us an idea of how the riots might have been incited. It takes the form of an official document, one emanating from an organization:

Goals:

\section{Return of Ancestral Goods Stolen by Various Chinese}

1. Enjoy this life

a. Visit the places of your friends and relatives

done)

b. Do whatever you have wanted to do (which you have not yet

have injured.

$$
\text { c. Ask pardon of PRIBUMI [non-"Chinese" Indonesians] you }
$$

Plans:

2. We have already decided that within a short time we will take back OUR ANCESTRAL WEALTH, by these means:

a. Burning Chinese HOUSES and WEALTH

b. Cutting off men's PENISES

c. Stripping naked men and women

d. Raping Chinese GIRLS 
Desirable:

$$
\begin{aligned}
& \text { Making Chinese males our chauffeurs } \\
& \text { Making Chinese women our servants }
\end{aligned}
$$

There is no other way to wipe out Chinese ARROGANCE, so long as [your] WEALTH and lives still exist, it cannot be done, [therefore] we have planned this as carefully as possible and now wait for the right moment [to carry it out]. We wish you peace in using well what life remains to you.

NB: Photocopy this for other Chinese

For Miss Pretty Chinese we will use a curtain rod as a LAMP WICK (we do not want to dirty our own goods).

\author{
Respectfully, \\ Pribumi Fighters
}

This document is widely called false. It is not believed to be the product of an organization called "Freedom Fighters" at all but rather to have been disseminated by elements from the army, perhaps the same elements thought to have been responsible for the riots of May. In any case, it displays some of the same structure of those riots. The document, distributed to "Chinese," is also in the hands of members of the underclass. It is not, however, likely to have been conceived by the latter. If, after seeing this document, they find it congenial, it is because the makers say what they, the recipients, think. But, one remembers, rape is new on the political scene and an invention, probably, of the army. The idea comes from somewhere else; the agreement of some of the underclass is not an accord between what they knew and wanted before May 13, 1998. Nonetheless, hearing what the document says, it comes to speak for certain of the underclass. It is not in the first place a representation of their wishes; only after the fact does it say what they want and what they think. It is similar to the workings of desire in the modern market. In the shopping mall, one finds things one never thought of before. But seeing them, somehow one knows that one has always wanted this particular jacket, that particular cap; one even feels one has needed them for a long time. If this is the way the events of May were stirred up, it means that the massa, in May 1998, materialized when someone spoke for it. First came a voice, the voice of a man in boots who descended from a truck, and then came a mass of people who learned that he said what they wanted to do. This incoherent group of people became the massa. When the booted man left, or when the massa were told the event was over, the massa disappeared, to be replaced with the inhabitants of the area who wanted "Chinese" to reopen their shops.

The goods taken from "Chinese" will be burned, not appropriated by looters. The enjoyment of wealth is postponed until society is restored through a reversal of conditions, "Chinese" being reduced to servants, pribumi becoming masters. This reversal is the conclusion of the banishment of desire in the present. If "we" want wealth back it is not in order to become wealthy, but to cease being bothered by what others have. When we have back what is rightfully ours, we can stop wanting; which is to say, we can get rid of desire itself. The good society will come into existence when 
104 James T. Siegel

desire is banished. At that point, the weaknesses of both national identity and kinship identity will be rectified.

Wealth in this document takes the form "our" goods in the possession of "Chinese" ("we will take back OUR ANCESTRAL WEALTH"); and wealth here is ancestral, the ancestors being "ours," not theirs. There is a double implication here. It may be that the "ancestors" are "Indonesians" as a whole or as type, and that national wealth has been stolen. Indeed, this charge is sometimes made against "Chinese." But the charge is usually made without the word indicating "ancestral." By adding that word, one implies that transmission through descent has been somehow perverted; what should have been passed down has taken a devious path and fallen into the hands of "Chinese." The strange recourse against "Chinese," castration and rape, makes descent impossible for them. "Chinese," I have noted, are often called "keturunan," "descendants," short for "of 'Chinese' descent," as though only "Chinese" had ancestors. Rape and castration suggest that in the thinking of these rioters-to-be, the end of descent for "Chinese" is the rectification of descent for pribumi.

Indonesia, in the conception of its founders, was based on its power to absorb the different ethnic groups of the archipelago and in so doing to form a new, single national identity. This power was fundamental to the formation of a unified nation. When "Chinese" are accused of being "arrogant," as they frequently are by their enemies, it means that they do not consort with "us," other Indonesians, whereas they ought to. They are blamed for refusing to do so, but one could just as well see in the accusation the implication of the failure of the power of the nation to assimilate its peoples. In its place, another hierarchy is set up, one where "we" are the drivers and the domestic servants of "Chinese." It is "Chinese" in this view, and not the Indonesian nation, who have the ability to relate people to one another.

They do so, it is charged, in an unfair manner. They steal "ancestral" goods, which are distributed by their rules among themselves. This vision of the "Chinese" as thieves is racist, but it is not based on a concept of racial purity; rather its opposite. "Chinese" are, in the view of anti-Sinites, not like Jews in the view of anti-Semites: they do not threaten genetic contamination. Rather their threat is that of the power to build a structure within the nation that exists by its own energies and has its own regulations. In the absence of the ability of Indonesia to absorb "Chinese," they, "Chinese," pull those who might form part of the massa into another structure, rather as though they had built a foreign state inside Indonesia. Rape, arson, looting at once destroy "Chinese" power and restore it to those who had lost it. ${ }^{32}$

Finally, we have this observation about the massa. They are thought to be Islamic. As Benedict Anderson pointed out to me, when the Christian Batak riot, they are not thought of as massa but as "Batak," defined by their ethnicity and not by their religion. The massa are a category of the nation and not of the regions. As a transformation of

32 If the events of May had not occurred, it would be difficult to take this document seriously, not so much for what it says, as for the strange form of its expression. Its offical format and its impoverished prose does not lead one to feel the wish of someone to say something. But the whole of the events of May were expressed in a nonserious prose, from the commercial rhetoric naming the softlens to this throwsheet. The seriousness of the event and the lack of seriousness of its languages are not in conflict. The ability to shift registers, to treat "Chinese" as valued acquaintainces one day and as ogres the next, depends on a certain lack of investment in language, one which, nonetheless, leads to grave consequences. 
"the people," they have much in common with Indonesians of the class above them. As should be apparent by now, the Indonesian middle class feels remiss about ignoring them because it partially identifies with them and fears them at the same time. In the minds of the middle class, the underclass is savage but it is also Islamic. The massa, biadab as they are, embody the potential subjects of a religious reformation in which rationality guided by religion learns to constrain cravings, wishes, and erotic energy. ${ }^{33}$ Such views were incompatible with consumerist New Order Indonesia during its prosperity and no doubt produced guilt at the moment of the economic crisis. The middle class cannot afford these ideas, but has never revised them. The violence of May 1998 constituted a perverse return of such religious thinking against those who believe. The Islam of the massa reflects the beliefs of the middle class about itself, showing it its own possibilities, while at the same time aggravating its guilt for having neglected the rakyat. ${ }^{34}$

The use of Islamic rhetoric and the attribution of Islam to the rioters, as when, for instance, "Allahu Akbar" was written on buildings in Arabic script to save them from destruction and or when the Arabic word $a i b$ was used to describe the stain of rape, indicate a projection of Islam onto the massa. At the same time, almost every important Muslim leader on the national scene condemned the riots even though some are not known for friendliness toward "Chinese." One cannot see these riots as led by the figures of national Islam. Indeed, the difficulty for many is, as I have said, that they were not led at all or that they were, even worse, misled. It seems to me an implicit assumption of much of the discussion of the riots that the lack of Islamic leadership aggravated the expression of unmediated desire.

The massa, a transformation or perhaps a remnant of the rakyat, are the product of the imagination of the middle class; they are the menace left once the body of the nation has divided in two and identity in both its forms, national and kinship, is thought uncertain. It remains only to bring the massa into existence. With the collapse of credit not merely in the economy but in the government, certain elements not from the underclass did bring the massa into existence. The result was rapid swerves in the sympathies and identifications of the middle class: with the looters and against them, sometimes against "Chinese" but now with "Chinese" women and against rapists, once with the government and now against it. All these motions are predicated on a fear of the revolutionary tendencies of the underclass, a fear cultivated by the government in different forms during the New Order: fear of Communism, fear of criminality, and fear of the massa. Now, only apparently paradoxically, the latest form of this fear is the government itself.

33 See my The Rope of God (Berkeley: University of California Press, 1969) for an explication of Islamic ideas of desire.

${ }^{34}$ Here one can note the response to the rapes by the segment of the Islamic community that refused to condemn the riots. Rapes, in their view, have not been proven to have taken place. The issue of rape is an attempt to blame Muslims. For them the rivalry between "Chinese" employers and Muslims is central: "Really, pity the poor Islamic community. So many facts about Muslim domestic servants raped by nonpribumi bosses and it's as though they are wiped out by the cases of rape from the middle of last May whose proof is not yet clear." One notes that the rape of domestic servants was not charged merely against "Chinese." Nuha, "Kecerobohan Majalah 'Jakarta-Jakarta"" [The Indecencies of the Magazine JakartaJakarta], Media Dakwah, August 1998, p. 14. 
106 James T. Siegel

Many Indonesians seem to feel that poverty is shameful and that the remedy.for poverty is wealth. ${ }^{35}$ At the same time, many of the same people feel that "Chinese," even poor ones, are inherently and shamefully wealthy. The doubt cast on descent and therefore on morality as such by wealth and by poverty were manageable when everyone was doing better economically. Such contradictions are perhaps common in every culture and do not matter except in times of crisis. The Indonesian nation during the New Order (I do not speak of its victims) could afford a racism which was only intermittently violent, one which gave a privileged place in the economy to certain "Chinese" but kept all of them out of public office and governmental bureaucracy as though they were shameful, and allowed them occasionally to be the victims of riots. There was an oscillation between shameful wealth (theirs) and wealth which covered shame (ours) that was tolerated even, perhaps, by some of its victims. Racism, though it originated well before the New Order, was a component of its chief policy, Development. But when the economic crisis, the "krismon," arrived, the balance of political and economic life was lost.

When the world economy affected the nation most immediately, not merely the workings of the national economy, but the very notions of ownership and circulation were placed in doubt. Rape means that one's most precious possessions are not one's own. To "own" becomes a dubious idea when there are people who can take anything. They caused irreparable loss, and not only to those raped, as the values of adabculture, politeness-which Indonesians relied on to keep things to themselves depreciated with the rupiah. Not only commodities but the most valuable private possessions shamelessly whirled into circulation.

It took rape to make clear that the violence inherent in the Indonesian political system was permanently harmful and that notions of culture and shame could not limit violence, the latter now as much a property of the political class as of the massa. The relations of wealth and shame are scarcely new to Indonesian culture. The economic modernization of the New Order, the invasion of the market, assumed them but left them little chance to develop in a manner that would safely accommodate the desires raised in a society of consumers. The events of May revealed their inadequacy in the face of economic crisis.

"Chinese," I have said, was a word that permitted massive theft. But Indonesians assumed there would be limit to such activities. Once the word "Chinese" permitted rape, the limits of Indonesian racism were surpassed. Rape threatened legitimate descent and the founding myths of Indonesia. It showed that the savagery out of which the nation arose could always return. The evolution of the nation was proven to have been driven by the pressure of a growing economy unmatched by concomitant cultural evolution. A culture of the market had developed rapidly. Desire was generalized while little was devoted to its mediation. One can ask, does the New Order have cultural achievements? None that were not banned and few even of those. A nation that relied on shame rather than sublimation to brake desire, to extend and transform it, and that conceived of sexuality in premodern form left itself open to the events of May.

35 On this topic see Siegel, A New Criminal Type in Jakarta. 
I admire the Indonesian women and men who are so bravely insisting that rape be made a public issue, its perpetrators punished, its victims understood, and that women be granted security. But it remains to be seen whether the continuing fear of the underclass and the impoverished cultural legacy of the New Order offers room for the important changes in the lives of women and men and for the true democratization Indonesia so painfully needs to prevent rape from being a permanent addition to the savage habits of Indonesian political life. ${ }^{36}$

\section{APPENDIX}

I do not want to underestimate the strength of feeling of "Chinese" who were so savagely attacked. Here are excerpts from one of the strongest statements of a merchant. It appeared in the weekly newsmagazine Forum seven weeks after the events. It was made by Hadi Wijaya, 47, owner of the optical store "Sinar" on the second story of the Glodok market as well as a second shop:

At the time of the crisis [krisis; meaning the economic crisis] I gave basic goods [sembako] to the poor. But now it's me that gets donations of basic goods from the vihara. That's the fate of my family since these riots.

Now, where the shop which used to be so busy was there is nothing but the stench of smoke and stifling, stinging ashes. The passageways are deep in darkness. In the corners the only thing to see are pellets of debris which used to be merchandise. There are sacks of the remains of contact lenses, all ruined, and contact lens bottles heaped up in what used to be a kiosk.

What can I say to my three children who are nearly adult now about this tragedy [tragedi]? Thirty years of work gone in a day. I never felt exclusive [eksklusif] and better than others. That I worked hard and got to be what I am today is only the result of never ending struggle. From the time I was ten I was selling on the street corners. Often enough I was picked up by the police, beaten, and lifted into a truck [to be brought to jail for selling without a license, presumably]. Even while selling on the street, I kept going to school till I had finished junior high school. I mixed with the other street sellers who were mainly pribumi.

"I began with nothing," Hadi Wijaya said, and then gave his mercantile history; how he cleaned other people's stores, saved his money till he had some capital, traded dishes, then recordings, and finally opened two optical stores.

\footnotetext{
36 Perhaps I should point out that what I have written above concerns only Jakarta. What happens next depends not only on Jakarta and the other great cities of the country, but what will occur as well in the provinces and the countryside. There is no space here for me to take up the question of how fear of the underclass is related, historically, to the idea of the emancipated Indonesian woman as a (mere) household manager. See Siegel, Fetish, Recognition, Revolution.
} 
108 James T. Siegel

How is it my business prospered? Its because I really worked. Not only that, I didn't fool around. Once in a while, a friend would say we should go somewhere but I always refused. It's better to save your money. Even eating, I always ate at home. With what I saved I opened an optical store in the shop house near where we live in Taman Harapan Indah. It's run by my brother-in-law.

At the time of the riots the thirteenth and fourteenth of May, both optical shops which took me decades to build were gone in a second. Our store in Harapan Indah was smashed and looted on the thirteenth of May. I saw with my own eyes, with my wife and children, how the massa smashed and ruined all our wealth. My child who is now at the university can't even get up from seeing this brutal, brutal looting ...

At the time of the events, I tried not to weep in front of my wife and kids. But after I sent them off to the house of my relatives in Angke, I wept till I had no more tears. Speaking of being afraid, we are still in the grip of fear. It's true, in the day time we dare to go out, but as soon as it gets dark, no one thinks of leaving the house. Trauma [English] isn't easy to get rid of. And what's more, the government still hasn't guaranteed our security, us the descendants [keturunan, meaning descendant and used now to mean "of Chinese descent"] ${ }^{37}$

Stories collected from Chinese men tend to have the same elements. They are stories about the injustice of the events. About the victims' entitlement to their possessions because they worked hard for them. Stories too about helping the poor who then robbed them and, not to be slighted, stories of the brutality of the rioters. There is sometimes too, as in this moving example, the pathos of having lost so much and of feeling oneself a victim in front of one's children and one's wife. The sense of personal diminishment is matched by anger at the government for its lack of protection and, as in this example, for not, even weeks later, promising to guarantee the victims' safety. This man is angry; the government should listen. He has, then, recuperated himself, and he expects that eventually he will be heard by, amongst others, "the government." The story moves from one of loss and humiliation to anger and to possible connection with the government. It ends on a tone of reassurance as it gives the foundation for the rebuilding of his life.

Among other effects, these stories lead to questions of the position of the Chinese, widely discussed in the press, and questions also of "Reform," "Reformasi," the slogan under which the change of regime was carried out. These stories, in other words, lead to discourses already in place. The voices of those looted are recorded and the expectation is that readers hear them. Discourse, if it was broken, is restored, aiding in the rebuilding of assurance.

I want to thank Budi Susanto, Henri Chambert-Loir, Benny Subianto, Rudolf Mrázek, Joshua Barker, Arndt Graf, and most especially B. R. O'G. Anderson for their comments on this piece and their contributions of material. I am responsible for the errors and they are responsible for much the reader finds accurate and well conceived.

Ithaca, New York, October 25, 1998

37 "Suara Hati: Kucuran Keringat Yang Mengering Sekejap" [Stories from the Heart: Torrents of Sweat Which Dried Up in a Flash], Forum Keadilan, July 13, 1998, p. 44. 